\title{
Prospects for individual economies
}

\section{United States}

In the last three quarters of 2017 output in the US, on an annualised basis, expanded by an average of 3 per cent a quarter, exceeding estimates of potential output growth. While recent data seem to indicate a weak start in Q1 in real GDP, this is expected to be transitory. Since the beginning of this year, employment has continued to grow strongly and survey-based high frequency indicators suggest further solid growth in the months ahead. Our forecast for GDP growth for 2018 at 2.7 per cent remains largely unchanged, with recent tax cuts and the enacted federal budget agreement expected to support the US economy in the short run.

However, there is uncertainty concerning the size and timing of the economic impact of the changes in fiscal policy. Issues such as the duration of the tax cuts, whether some of them remain temporary or will be made permanent; the impact from an increase in the budget deficit on fiscal sustainability and interest rates; and the introduction of a fiscal boost while the economy is already operating near its potential; are all factors that make assessing the effect of the changes difficult.

\section{Figure 5. US: GDP growth and inflation}

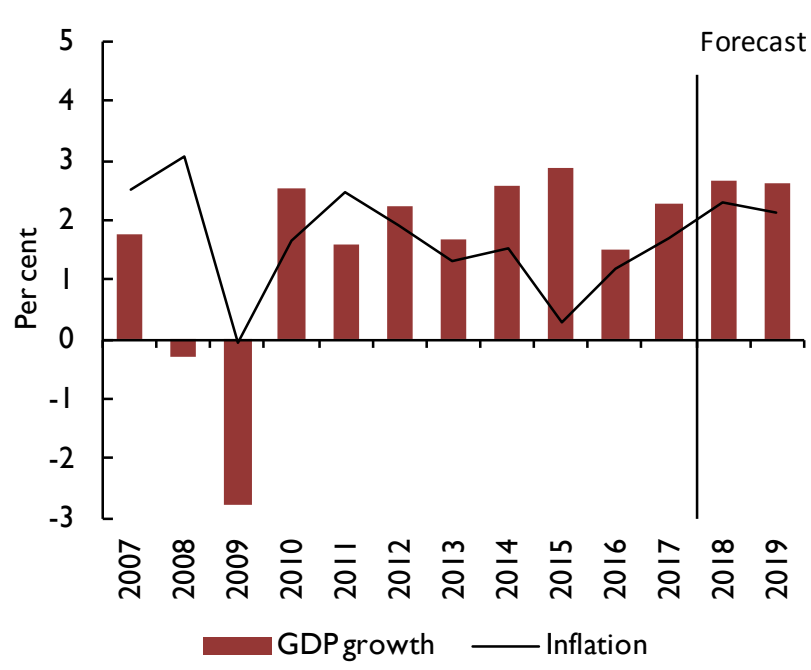

Source: NiGEM database and NIESR forecast.
Since the publication of our February Review, uncertainties associated with trade policies have increased. On their own, recently imposed tariffs on imported steel and aluminium are not expected to have a significant impact on US economic prospects. However, the possibility of introducing tariffs on a wider range of imported goods and any retaliatory trade actions by other countries have already led to an increase in volatility in some parts of financial markets. Since the end of January, US equity prices have declined by about 6 per cent, yields on longterm government bonds have increased and corporate bond spreads widened.

The labour market has remained strong with payroll gains continuing to outpace the rate of absorption of new entrants into the labour force. Recent gains in the labour force participation rate have meant that the unemployment rate has remained low and unchanged at 4.1 per cent for the past several months despite a significant increase in payroll numbers (see figure 6). While tax reforms can bring more of the population into the workplace, labour force expansion is restricted by demographics.

Figure 6. US: Unemployment and labour force participation rate

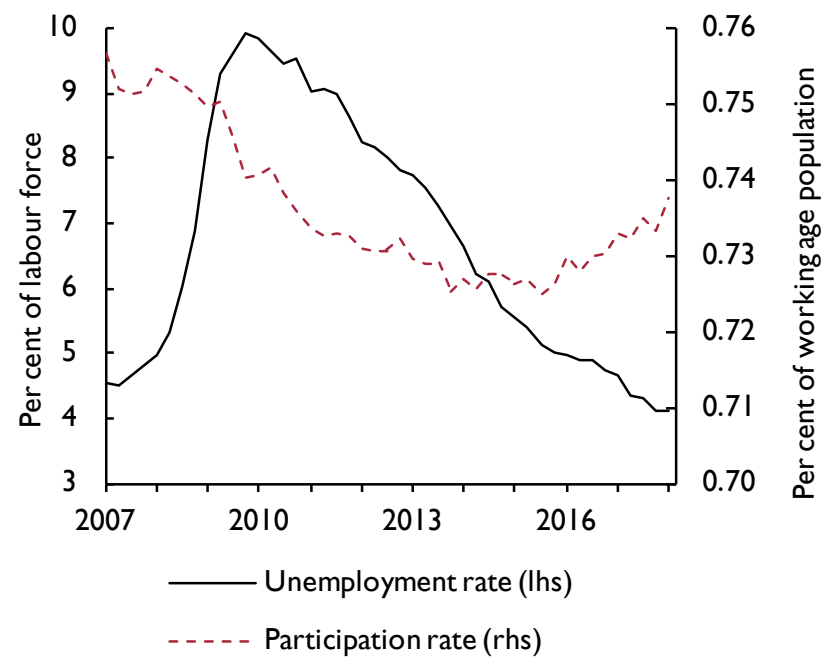

Source: NiGEM database and NIESR forecast. 
Wage growth has continued at a modest pace, consistent with weak productivity growth. Average hourly earnings for all employees on private non-farm payrolls have increased in the 2.6-2.8 per cent range in the first three months of the year on a 12-month basis. Inflationary pressures have been limited so far. Inflation, based on a 12-month percentage change in the personal consumption expenditures price index (PCE), remained below 2 per cent in both January and February. Looking ahead, we expect inflation to reach and remain around 2 per cent this year, supported by the fiscal boost when the economy is already near its potential.

\section{Canada}

On balance, the outlook for the Canadian economy remains positive. While the outturn of quarterly GDP growth in the final quarter of 2017 was (at 0.4 per cent) slightly lower than we had expected, early indicators for the first quarter of 2018 paint an optimistic picture. The main reason for the more modest expansion at the end of 2017 was high import growth, fuelled by buoyant business investment. In all three months of 2018Q1, the manufacturing PMI reached levels above 55 index points, signalling business conditions substantially better than average. According to the Bank of Canada's Business Outlook Survey, 73 per cent of firms expect greater or similar sales growth over the next twelve months relative to the previous year. While capacity pressures have eased somewhat in the first quarter of 2018 compared to the

Figure 7. Canada: Headline and core inflation

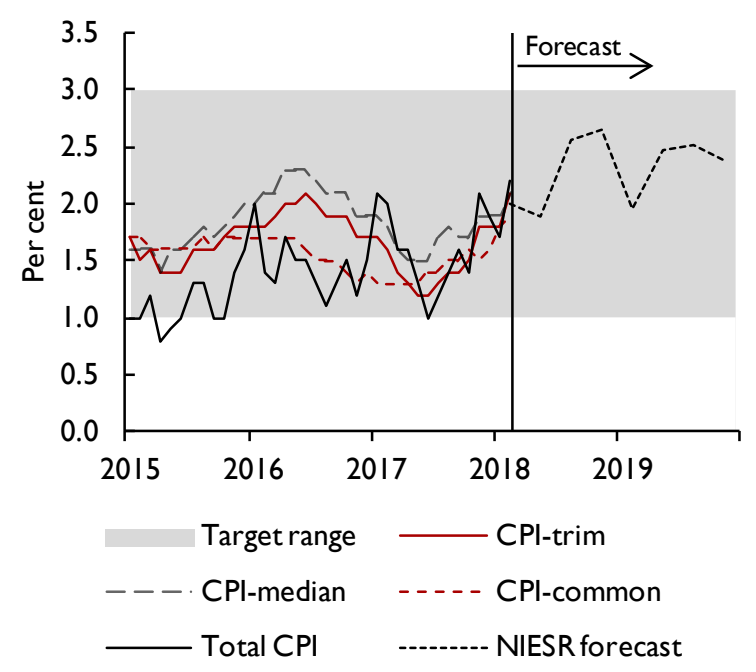

Source: Bank of Canada and NIESR.

Note: NIESR forecast is for change in consumer expenditure deflator. previous quarter, 26 per cent of firms continue to report labour shortages as the unemployment rate remains at its 10-year low of 5.8 per cent. Labour market tightening now appears to be translating into higher wages, with average hourly earnings increasing by more than 3 per cent compared to a year earlier in the first quarter of 2018. This means that headline inflation and all of the Bank of Canada's preferred measures of core inflation moved up to the middle of the central bank's target range of 1-3 per cent in February (figure 7). We expect inflation to remain around 2 per cent over the next two years, assuming that the Bank of Canada continues to raise its policy rate at a very gradual pace. For 2018 as a whole, we forecast output growth of 2.6 per cent, easing slightly to 2.3 per cent in 2019 . Stable inflation and robust growth are consistent with the view that firms are increasingly building up productive capacity. The fact that intentions to invest continue to be high, supported by still easy credit conditions, also points in that direction.

Despite robust growth and steady inflation, some concerns remain. While pressure on the real estate market has recently eased slightly in response to tighter mortgage regulation, the persistently high level of household debt (at 170 per cent of disposable income) remains an important risk to financial stability. In addition, uncertainty about the country's trading relationship with the US, its largest trading partner, keeps increasing. While tariffs on metal exports have been dodged for now, the renegotiation of NAFTA continues to be a risk. If no clear agreement is reached soon, this will likely dampen the investment outlook. While still being in the minority, the share of companies that reported an impact of US policy uncertainty on their business in the first quarter of 2018 has increased to 21 per cent, up from 10 per cent a year earlier.

\section{Euro Area}

The Euro Area economy expanded by 0.6 per cent in the final quarter of 2017, the same pace as in the third quarter. With 2.5 per cent annual growth in 2017, this was the strongest since the start of the Great Recession. Consumer spending growth was consistently strong but investment growth proved more volatile during 2017, as did net trade. Despite the strengthening of the euro, export growth has been running at over 1 per cent a quarter for the past year. The latest activity indicators have continued to be robust - the IHS Markit Composite PMI in March showed 55.2. Our expectation is that the momentum from 2017 will lead to the first half of the year showing stronger growth than the second, with some monetary indicators already hinting at a 
Figure 8. Euro Area: exchange rate (US\$ per one euro)

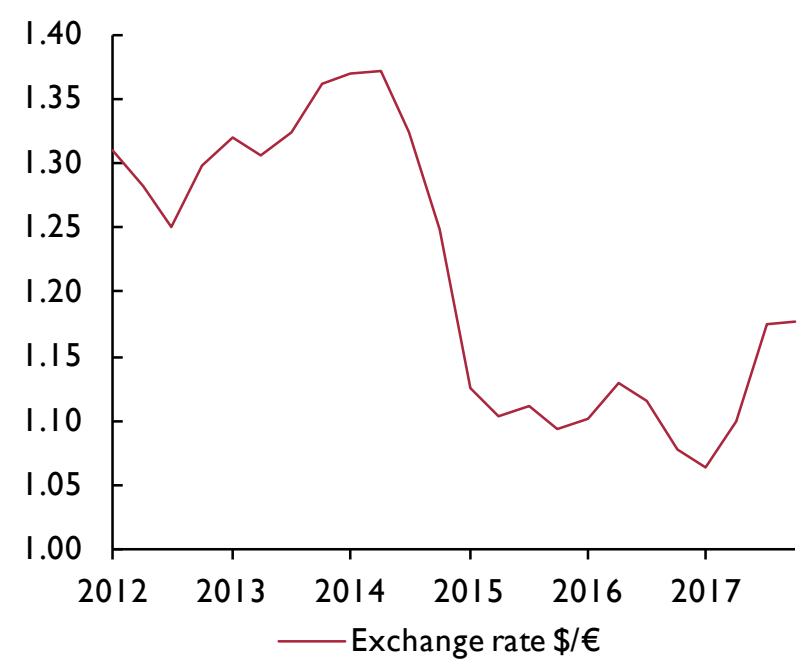

Source: NiGEM database

weakening of growth prospects. But with GDP growth of 2.3 per cent forecast this year and a further, but slightly slower, 1.9 per cent next year as the near-term momentum fades, the prospect is for the Euro Area to continue to show robust growth. Some weakening may come from the gradual reduction of the monetary accommodation and the recent appreciation of the euro relative to the US dollar, which could dampen the pace of export growth.

Consumer price inflation was 1.3 per cent in the twelve months to March, the same as in January, well below the 2 per cent target despite the extent of the monetary stimulus provided by the ECB. While last year saw an increase in the rate of inflation of around 1 percentage point, our near-term expectation is that the rise in inflation has stalled and we expect inflation to remain below 2 per cent in both 2018 and 2019.

The unemployment rate fell to 8.5 per cent in February. This was about 1 percentage point lower than a year earlier and the lowest since early 2009 . The youth unemployment rate at 17.7 per cent remains substantially above the adult rate ( 7.7 per cent) although the percentage point gap in these rates has fallen over recent years. The unemployment rate is expected to fall further in the near term especially as the job vacancy rate is already at a high point, but the pace of further reductions is expected to be slow.
Figure 9. Euro Area: GDP growth and inflation

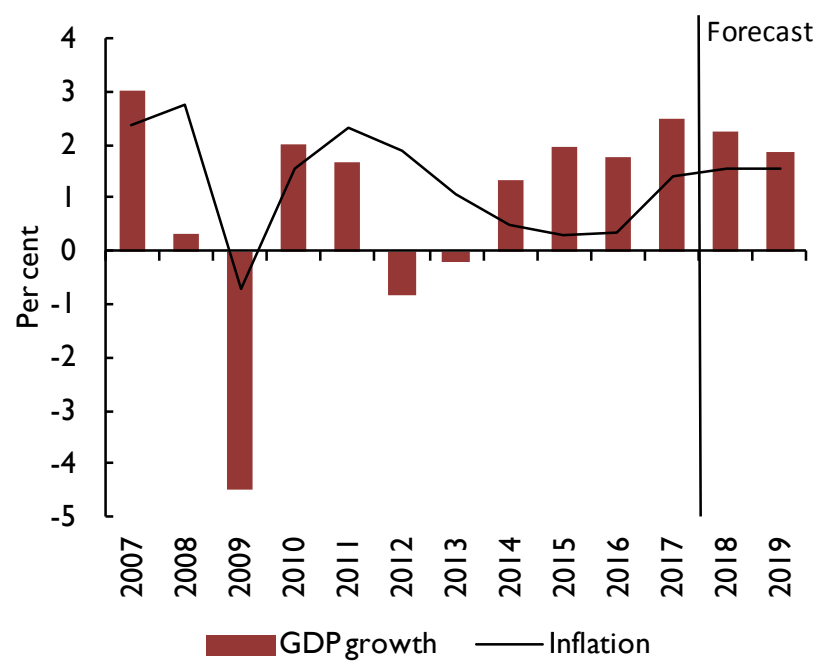

Source: NiGEM database and NIESR forecast.

The policy stance of the ECB will continue to be a focus for financial markets and the forecast incorporates current policy statements and forward financial market views. The expectation is that quantitative easing will end after September this year, since the pace of asset purchases has already reduced to $€ 30$ billion a month. But the ECB is likely to be watchful and, especially with continued below target inflation, is not expected to tighten monetary policy in a marked fashion.

\section{Germany}

After relatively rapid growth in 2017, the German economy continues to experience a robust expansion, but with perhaps somewhat less steam. After GDP growth of 0.6 per cent in the fourth quarter of 2017, supported by net trade and investment, indicators for the first quarter of 2018 have slightly softened. Growth in industrial production and new orders in manufacturing have remained solid but were weaker in February than January. The IFO Business Climate index eased to 102.1 in April from 105.0 in December, mainly because of less optimistic expectations. For the whole of 2018, we forecast GDP growth of 2.4 per cent, compared to 2.5 per cent in 2017. Within the total, we expect strong contributions from domestic consumption and investment. Support from foreign demand may soften over the course of the year as a result of the stronger euro. In 2019, output growth is expected to edge below 2 per cent. Fiscal policy will likely mitigate the lessening in growth but 
capacity constraints appear to be increasingly binding, especially with the unemployment rate falling to 3.4 per cent in March. Labour force participation of refugees has recently increased but not at a rate sufficient to meet labour demand, while immigration is expected to reduce in 2018, given the widespread economic recovery in Europe.

Despite the tight labour market, real earnings growth remained subdued at 0.5 per cent in the final quarter of 2017 (0.8 per cent in 2017 as whole). An agreement between the IG Metall labour union and employers in the South West's metal sector in February - widely seen as indicative for the rest of the economy - shows that, while wages are likely to rise more in 2018 , employees appear to be more willing to forego higher wages in return for reductions in weekly working hours and a better work-life balance. With energy prices expected to rise only moderately, we forecast inflation to remain below 2 per cent over the forecast horizon.

Over four months after the general election in 2017, a new government of the conservative Christian Democrats and left-of-centre Social Democrats was formed in March 2018. A number of measures have been agreed to support investment growth and raise households' disposable income. Spending on infrastructure will rise, welfare benefits and pensions will be increased and national insurance contributions of employees will be relaxed. The German Institute of Economic Research,

Figure 10. Effect of the German fiscal stimulus on annual GDP growth (difference from base)

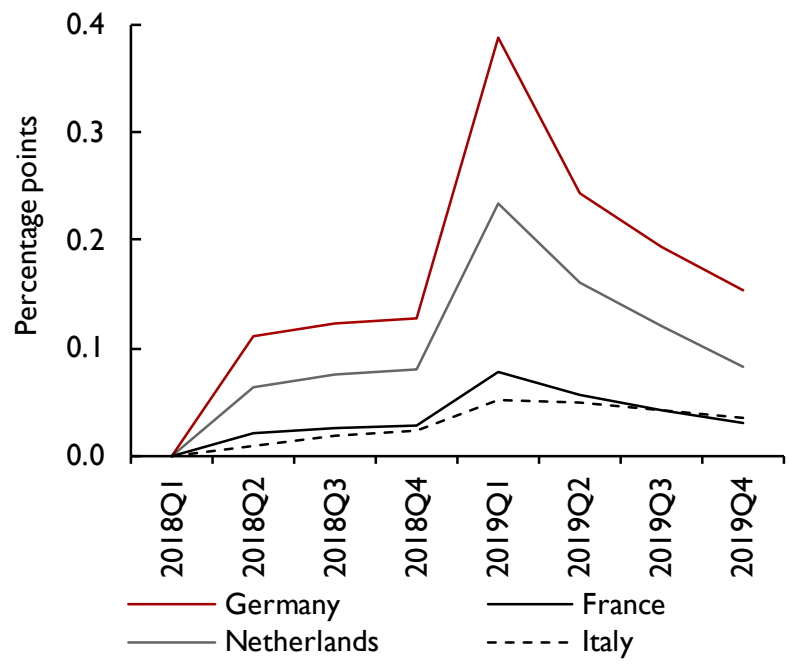

Source: NiGEM simulation based on data from German federal government, DIW Berlin.
DIW, calculates that this will raise government spending by $€ 10.3$ billion in 2018 , and $€ 27.3$ billion in 2019 . Our forecast of government consumption and investment now reflects this change in stated government policy. We have also estimated the effect on the economy using NIESR's global econometric model NiGEM. Figure 10 shows that the additional fiscal spending and lower social security contributions are expected to add around 0.1 percentage points and 0.2 percentage points to annual GDP growth in 2018 and 2019, respectively. The impact on Euro Area growth is around half that size, with countries with strong trade links, like the Netherlands, benefiting from a spillover effect about two thirds of the impact on German growth. (For a detailed discussion of Euro Area responses to German fiscal policy shocks see the article by Jorra et al. in this Review). Overall, the stimulus is not large, partly because the government has promised to stick to a balanced budget, an objective that, according to our estimates, will not be endangered by the additional spending.

\section{France}

The French economy expanded in 2017 by 2 per cent after only 1.1 per cent in 2016. In the fourth quarter of 2017 , GDP growth accelerated slightly to 0.7 per cent from 0.5 per cent in the previous quarter, thanks to the strong contribution of exports, which grew by 2.5 per cent in the quarter. Household consumption growth was subdued at 0.2 per cent in the quarter as real personal disposable income was hit by an uptick in consumer price inflation which increased from 0.9 per cent in the third quarter to 1.2 per cent in the fourth quarter. Fixed investment grew at around 1 per cent for the third consecutive quarter, recording annual growth of 3.8 per cent for 2017.

Improved business activity led to an increase in tax receipts and a subsequent reduction in the government deficit to 2.6 per cent of GDP in 2017, below the 3 per cent threshold of the Maastricht treaty. For the first time in ten years, the ratio of debt to GDP is forecast to decline in 2018. Fixed income markets have welcomed this news and the yield premium for the French 10-year bond over the equivalent German one reached an 8-year low of 16 basis points in February 2018.

Growth in the French economy stuttered a little at the start of 2018 to 0.3 per cent. Industrial production decreased by 0.4 per cent in the three months ending in February and in March both INSEE's business climate indicator and Markit's service sector PMI were off their peaks reached in the second half of last year. However, most recent indicators still point to continued robust year-on-year growth: sales in wholesale and retail in 
Figure II. France: GDP growth and inflation

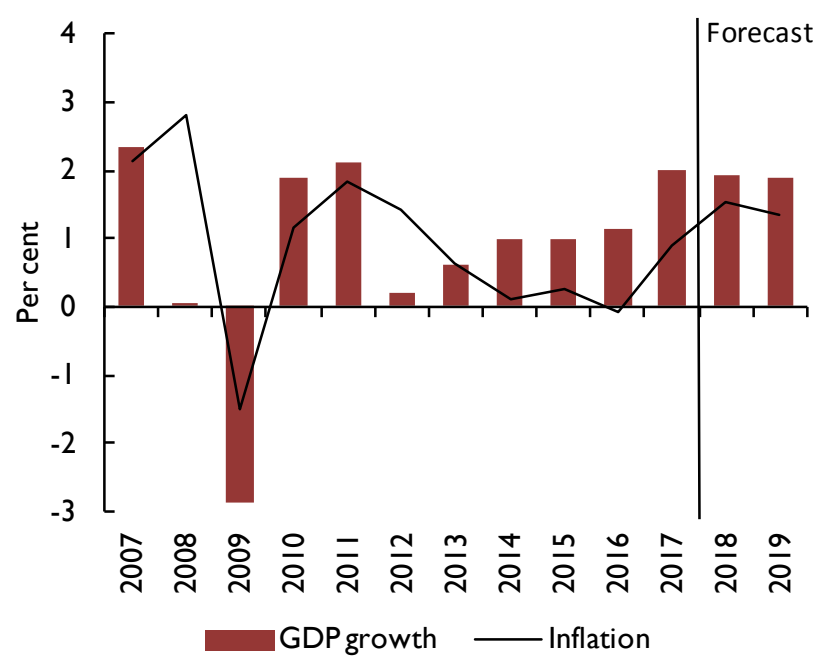

Source: NiGEM database and NIESR forecast.

January 2018 were up by 3.9 per cent from January last year and industrial output in February 2018 was up by 4 per cent from the same month last year. Two recent headwinds support a cautious outlook: the disruptions caused by extremely low temperatures at the end of February and the ongoing strikes at the national railway operator SNCF. With risks balanced between the upside (momentum) and the downside (short-term disruptions), we maintain our GDP growth forecast close to 2 per cent in both 2018 and 2019. We expect a stronger contribution to growth from net trade, largely driven by the improvement in labour cost competitiveness of the past five years, and a temporary uptick in inflation.

\section{Italy}

Last year's GDP growth of 1.5 per cent was the strongest since 2010, but even so it was substantially below the Eurozone's average of 2.5 per cent. Output is expected to grow again by close to 1.5 per cent in 2018 and 2019, above our estimate of potential growth. The headline inflation rate (HICP) reached 1.3 per cent in 2017, the highest since 2013, although it dipped below 1 per cent in the first quarter of 2018 . We expect it to stabilise at just over 1 per cent this year and then to converge slowly to just below the inflation target by the end of our forecast period, with the slack in the labour market remaining sizeable and likely to decrease over the forecast period. The unemployment rate was at 11.3 per cent in 2017, down from 11.7 per cent in 2016, and we expect it to be below 11 per cent over the coming years.
Figure 12. Italy: GDP growth and inflation

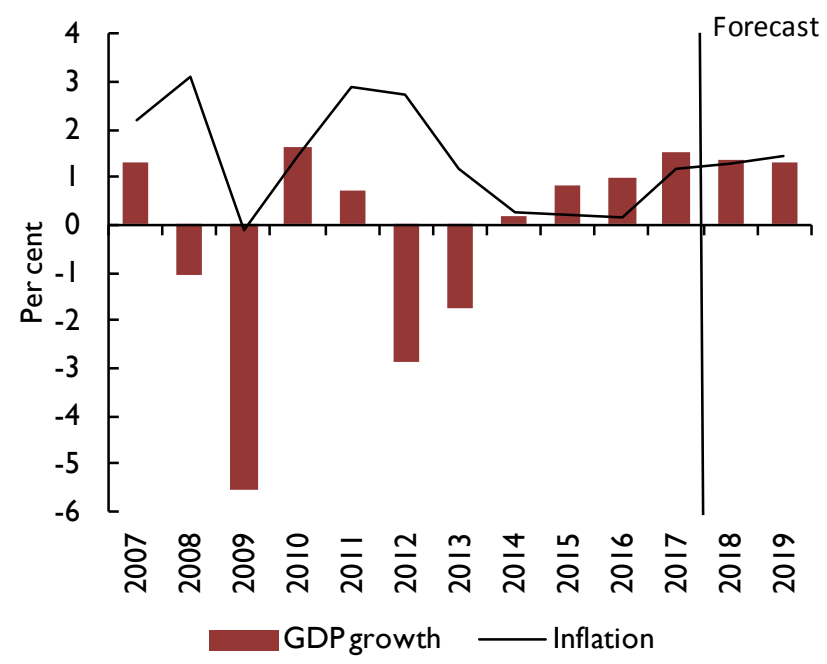

Source: NiGEM database and NIESR forecast.

The recovery in growth has been a domestic demanddriven story, in particular with consumption and private sector investment having added 0.8 and 0.7 percentage points respectively to GDP growth in 2017. Some economic sentiment indicators are softening from the very elevated levels reached in 2017, but the consumer confidence index in March increased to a record high.

Although the pace of the recovery has strengthened, structural problems in Italy remain; public sector debt remains high and unemployment is still significantly above the Euro Area average. Stagnant productivity and possible financial fragility remain threats to the medium-term growth projections. The general elections that took place last March led to a hung parliament and the uncertainty in the election outcome poses a further strain on these issues as it may lead to a period of lack of reforms as well as potential repeal of some of the structural reforms already in place. Most political parties have called for a shake-up of the fiscal austerity programme as well as for more protection for workers, and for lower taxes to support spending. These could be contentious issues for the relationship with the EU as well as posing upside risks to our projection of the government budget balance. While public debt has stabilised, it remains vulnerable to rises in interest rates (which we forecast for late 2019) and to the outcome of the negotiations underway for a coalition government. 


\section{Spain}

Spain's strong recovery since the financial crisis has continued. According to the latest set of national accounts, economic growth exceeded 3 per cent in 2015, 2016 and 2017. The engine of growth in 2017 was domestic demand, particularly gross fixed capital formation, which was reinforced by a current account surplus. Rising activity has been associated with falling unemployment which, while 10 percentage points below the crisis peak, at 16 per cent is still substantially above pre-crisis levels and the Euro Area average. Unemployment rates for young people (at 35 per cent) remain high. Despite these indications of a substantial amount of labour market slack, prices rose by 2 per cent in 2017, in line with the ECB's definition of price stability.

We anticipate that these favourable economic trends will continue, but to a lesser extent as the post-crisis rebound fades. Real GDP, for example, is anticipated to grow at 2.5 per cent in 2018 and 2.0 per cent in 2019 . The unemployment rate is expected to decline to 15 per cent this year and 13 per cent the year after. Consumer price inflation is forecast to fluctuate between 1 and 2 per cent throughout the forecast horizon. In terms of risks, the momentum of the global economy continues to provide an upside risk, while a re-ignition of political uncertainty over the issue of Catalonian independence remains on the downside.

\section{Figure 13. Spain: GDP growth and inflation}

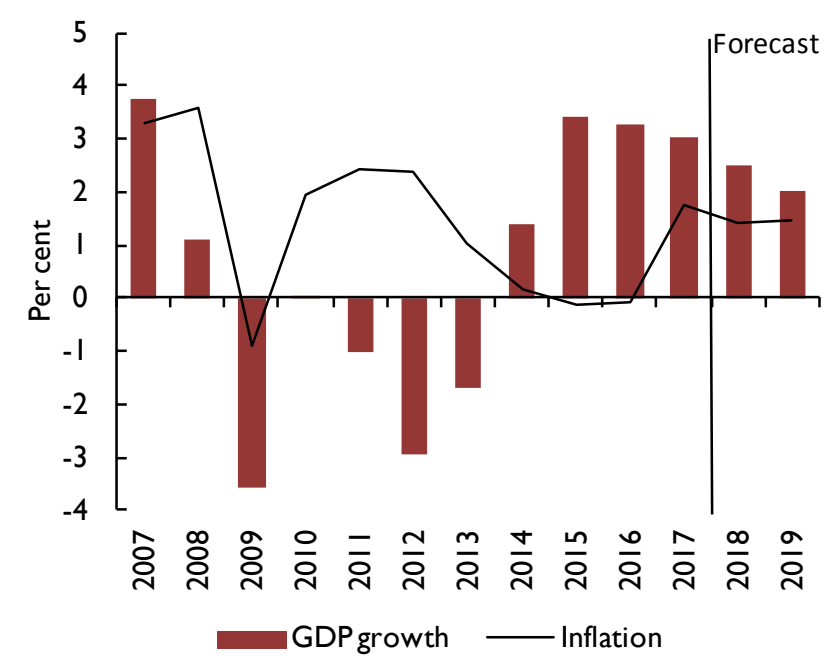

Source: NiGEM database and NIESR forecast.

\section{Japan}

The economy grew by 0.4 per cent in the final quarter of 2017, the eighth consecutive quarter of growth. Consumption and business investment were both strong, which is welcome news following a recovery that has been largely driven by export growth. However, we do not expect this momentum to be maintained into 2018 as the economy is likely to start to run up against capacity constraints. We forecast growth to average 1.2 per cent in 2018.

The unemployment rate fell sharply to a 24 -year low of 2.4 per cent in January 2018, from 2.8 per cent in the previous month, before rising slightly to 2.5 per cent in February. Strong growth following five years of economic stimulus coupled with Japan's declining working age population have led to reported severe labour shortages. The Tankan employment index, which measures the percentage of firms reporting that they have surplus workers minus the percentage reporting insufficient workers, fell to a 27 -year low of minus 38 for non-manufacturing firms in the first quarter of 2018 (see figure 14). In response, the government is planning a review of visa rules with the aim of increasing the numbers of skilled foreign workers.

Despite this labour market picture, there has been very little apparent upward pressure on wages and inflation has been well below the Bank of Japan's 2 per cent

Figure 14. Japan: labour market pressures

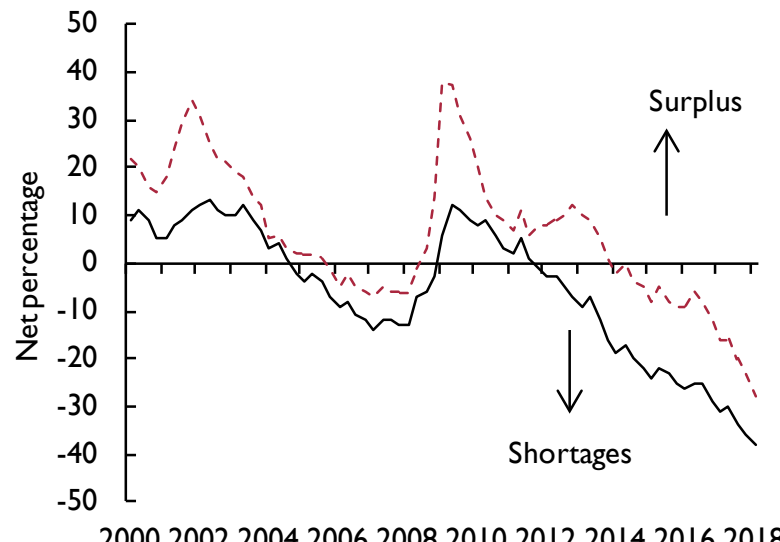

— Non-manufacturing _- - - Manufacturing

Source: Datastream, Tankan employment index. 
target. Consumer prices rose by 1.5 per cent year-on-year in February 2018, following a 1.4 per cent rise in the previous month. Real wages fell by $1 / 2$ per cent year-onyear in February 2018, following a contraction of 0.6 per cent in the previous month. We expect inflation to average 0.8 per cent this year and 1.3 per cent in 2019.

Government debt continued to increase in the last quarter of 2017. Since low interest rates mean that Japan's debt servicing costs are actually relatively low at around 14 per cent of GDP, this debt is not as fiscally unsustainable as it may initially seem. Nevertheless, it may reduce Japan's ability to weather any adverse economic shocks that may occur and thus continues to present a downside risk to our forecast.

\section{China}

Last year the Chinese economy expanded by 6.9 per cent - above the government's initial target of "about 6.5 per cent" growth - with investment in public infrastructure, consumption growth and foreign demand all contributing to strong performance. In the first quarter of 2018 GDP growth remained strong and reached 6.8 per cent on a year-on-year basis. We continue to forecast a gradual slowdown in the pace of output growth as the economy continues its longer-term path towards rebalancing.

Some policies are likely to become less accommodative in the current year and so weigh on the economic performance. Tighter financial regulation has already been applied in 2017 , and this looks likely to continue

Figure 15. China: Change in money supply (M2)

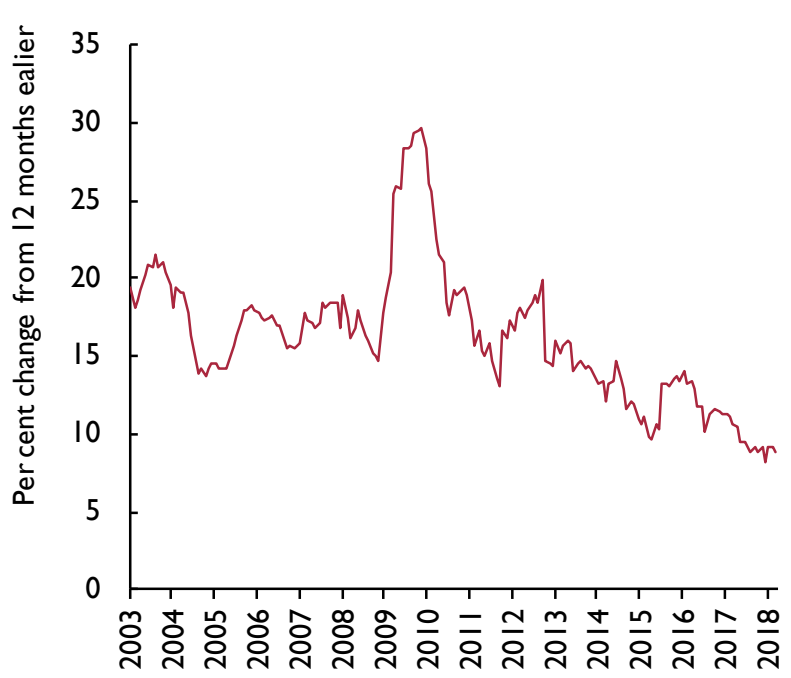

Source: Datastream this year as well. Even though new regulatory rules are not yet finalised, banks have already moved some of their off-balance activity back into the balance sheet, which may have contributed to a slowdown in the money supply growth (see figure 15). In March the People's Bank of China (PBOC) increased the rate on 7-day reverse repurchase agreements by 5 basis points to 2.55 per cent, which is used as a tool to control liquidity in the financial system.

Fiscal policy seems likely to become less expansionary. The government aims to stabilise the debt/GDP ratio and to scrutinise local government financing rules. This may lead to a reduction in infrastructure investment projects, which until now were used as a reliable way of helping to achieve "desirable" GDP growth.

Since the publication of our February Review there have been significant developments concerning the China-US trade relationship. On 23 March America formalised tariffs on steel and aluminium from a selection of countries, including China. In response, China placed tariffs on about $\$ 3$ billion of American exports to China. Then on 3 April the Office of the United States Trade Representative (USTR) published its proposal to impose a 25 per cent tariff on more than 1,300 Chinese products. A day later China responded with a proposed counter list, which matched both the magnitude (US $\$ 50$ billion) and the tariff rate (25 per cent) of those proposed by the US. Implementation dates have not yet been set and most probably depend

Figure 16. China: GDP growth and inflation

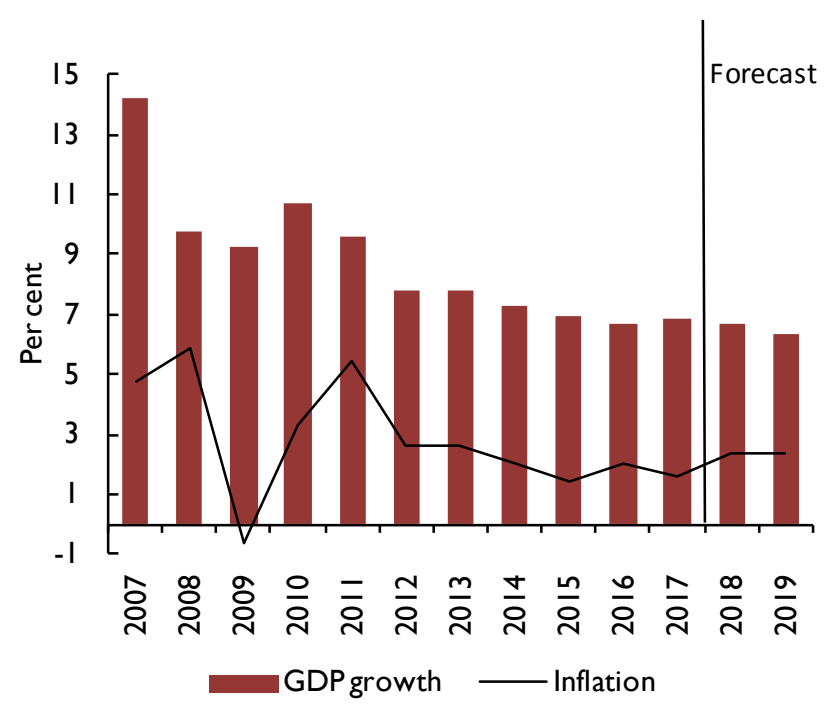

Source: NiGEM database and NIESR forecast. 
on how the negotiations progress. We believe that it is in both countries' interest to co-operate, but the issues appear as much political as economic.

\section{Russia}

Economic activity stabilised in 2016, with GDP contracting by just 0.2 per cent in the year as a whole, after the recession that began in mid-2014. Since then, economic growth has been on an upward trajectory. However, GDP growth slowed down in the fourth quarter of 2017 to 0.9 per cent from 2.2 per cent in the second quarter. This seems to have been somewhat of a temporary phenomenon as industrial production growth returned to positive territory through January and February. However, international sanctions remain a factor hindering recovery: in addition to the EU's extension of its economic sanctions until 31 July 2018, President Trump signed into law new sanctions in retaliation for the Russian government's alleged meddling in the 2016 US elections in early August. The risk of prolonged sanctions remains elevated. Taking into account also the economy's long-established structural problems, we forecast GDP growth of 1.9 per cent in 2018 as a whole followed by 2.3 per cent growth in 2019 .

Consumer price inflation, on a 12-month basis, picked up to 2.4 per cent in March from a historic low of 2.2 per cent in February. Having peaked at 16.9 per cent in the year to March 2015, inflation has thus fallen below the

Figure 17. Russia: GDP growth and inflation

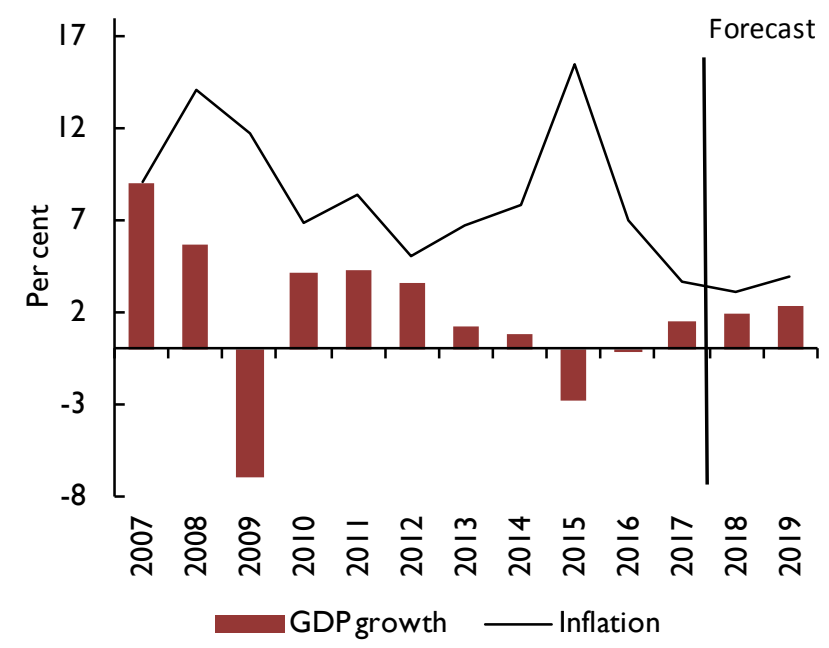

Source: NiGEM database and NIESR forecast.
Central Bank's target of 4 per cent. The high base effect from last year's food price inflation should continue to exert downwards pressure on annual inflation through the first half of 2018. This has been supported by the relative strength of the rouble against the US dollar, with the Brent Crude oil price in the mid-60s weighing down on imported inflation as well.

Following six reductions in interest rates from 10 to 7.75 per cent in 2017, the Central Bank lowered its benchmark interest rate in mid-February to 7.50 per cent and in late-March to 7.25 per cent. The Governor suggested that the Bank will continue its gradual transition from moderately tight to neutral monetary policy with the likelihood of further rate reductions in 2018. We expect inflation to remain slightly below the target as the economy continues its recovery in 2018 .

\section{India}

Output expanded at an annualised rate of 7.2 per cent in the final quarter of 2017, with India overtaking China as the world's fastest growing major economy. This marks a return of faster growth after disruption due to demonetisation in November 2016, when all 500 and 1000 rupee notes ceased to be legal tender, and the tax system overhaul in July 2017. We expect growth to average 7.7 per cent this year and 7.9 per cent in 2019 . The most recent budget contained measures to appease small business owners and poorer rural voters ahead of next year's general election, including higher minimum prices for farmers and free health insurance for poor families. However, these come at the cost of increasing the deficit target for the fiscal year starting 1 April 2018 to 3.3 per cent of GDP, reneging on last year's promise to reduce the deficit to 3 per cent. Lower than expected tax revenues following the general sales tax reform mean that the deficit for the 2017/18 fiscal year is expected to be 3.5 per cent, significantly overshooting the 3.2 per cent target.

Following over 25 years of increasing openness to trade, with weighted average tariffs falling from 56 per cent in 1990 to just over 6 per cent in 2016 (see figure 18), India has recently taken a more protectionist stance, increasing tariffs on a range of products from electronics to chickpeas in a bid to boost domestic production. This strategy is likely to harm domestic producers who rely on imported components as well as pushing up consumer prices. So although inflation fell to a four-month low of 4.4 per cent year-on-year in February, down from a peak of 5.2 per cent in December 2017, we forecast inflation to average 4.1 per cent this year, rising to 4.3 per cent in 2019. 
Figure 18. Effectively applied weighted average tariffs

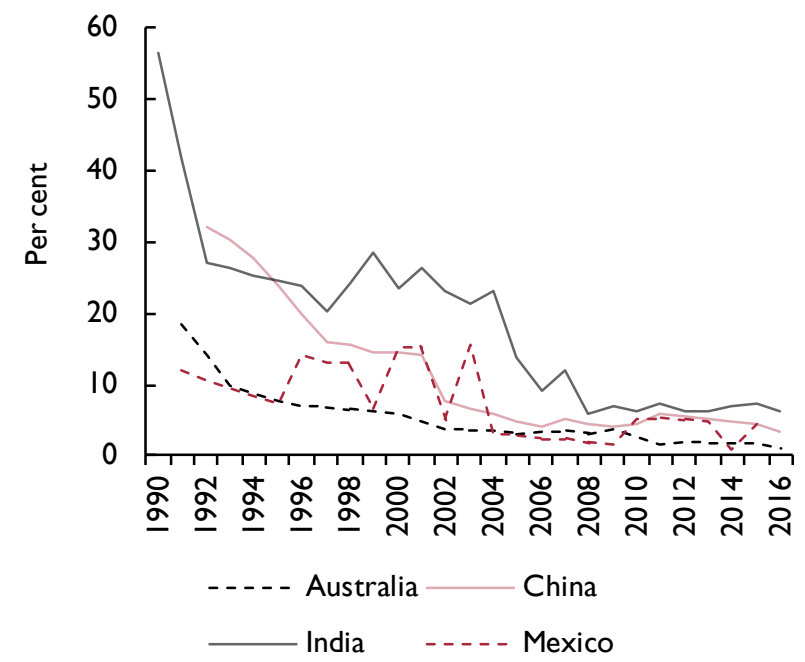

Source: The World Integrated Trade Solution.

\section{Brazil}

After recovering from a deep recession that took away 8 per cent of economic output from 2014, in 2017 GDP growth was close to 1 per cent. The recovery in output has been driven by stronger domestic demand which, in 2017, recovered after falling by around 6 and 5 per cent in 2015 and 2016 respectively. The pick-up in domestic demand materialised on the back of slowing price pressure and higher real wages supported consumption. High frequency indicators, such as manufacturing PMI and business confidence show growth continuing.

Our projections for GDP growth for this year and next are of 1.8 and 2.3 per cent respectively as a consequence. Faster growth is partly due to stronger consumption, supported by the better outlook for real wages given falling unemployment, which peaked in March 2017 at nearly 14 per cent and then edged down in the course of 2017 (although it has gone up slightly at the start of 2018). The regional as well as global upturn in demand will continue to help Brazilian exports and aid the trade position, moving the current account deficit from almost nil in 2017, into positive territory over the forecast horizon.

Annual consumer price inflation fell from a peak of almost 9 per cent in 2015 to just above 3 per cent last year. That allowed the Central Bank to decrease the policy rate to 7 per cent in December and again to 6.75 in February. We expect inflation to consolidate within the Central Bank's

\section{Figure 19. Brazil: GDP growth and inflation}

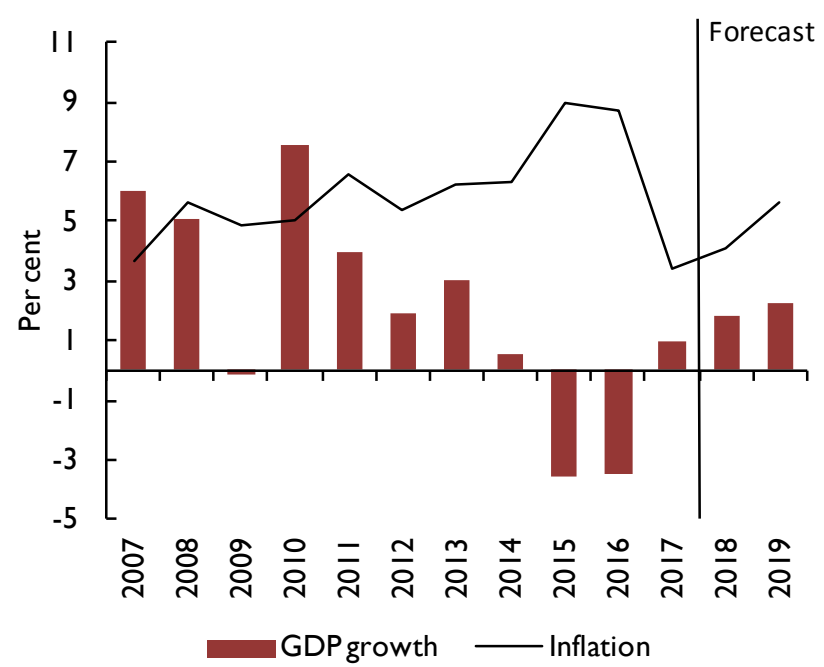

Source: NiGEM database and NIESR forecast.

target of 3-6 per cent this year and next and to provide support for accommodative monetary policy, which will further support investment. The risks to this forecast are tilted to the downside due to the elections due in October 2018 and to the fiscal position. The fiscal deficit remained at 8 per cent in 2017, leading to an increase in the debt-to-GDP ratio to 74 per cent last year.

\section{NOTES}

I See Box D in this chapter and Jorra et al. (2018) and Slopek (2018) in this Review.

2 See National Institute Economic Review (2016), 237, August and 238, November.

3 The Vix index is seen as a barometer of investor sentiment and market volatility and is a measure of market expectations of uncertain volatility implied by S\&P 500 index option prices.

4 See Box A in this chapter.

5 See National Institute Economic Review (2018), 'Disappointing productivity growth: an international dimension', 243, February and Chadha, J.S., Kara, A. and Labonne, P. (2017), 'The financial foundations of the productivity puzzle', National Institute Economic Review, 24I, August.

6 See Box B in the UK economy chapter of this Review: 'Decomposing wages: the productivity gap persists', and Royal Economic Society 2018 Annual conference, NIESR 80th Anniversary special session 'Productivity puzzles: past and present'.

7. Rudebusch, G.D. (2016), 'Will the economic recovery die of old age?, FRBSF Economic Letter, 2016-03, February.

8 See Liadze, I. and Haache, G. (2017), 'US monetary policy and its impact on emerging market economies', National Institute Economic Review, 240, May. 